\title{
ANALISIS CEMARAN MIKROBA PADA IKAN ASIN AIR TAWAR DI SAMARINDA
}

\author{
Elsa Edita ${ }^{1, *}$, Islamudin Ahmad ${ }^{1}$, Rolan Rusli ${ }^{1,2, \dagger}$ \\ ${ }^{1}$ Laboratorium Penelitian dan Pengembangan Kefarmasian "Farmaka Tropis", \\ Fakultas Farmasi, Universitas Mulawarman, Samarinda \\ *Email: elsaeditaproposal@yahoo.com \\ ${ }^{2}$ Kelompok Bidang Ilmu Kimia Farmasi, Fakultas Farmasi, \\ Universitas Mulawarman, Samarinda \\ †Email: rolan@farmasi.unmul.ac.id
}

\begin{abstract}
Food borne disease is recently happening in society, due to biological and chemical contamination in food. Fish is one kind of food which has a high chance to contaminated by biological and chemical compounds because disintegration process. One way to prevent contamination is preserving with making a salted fish. This research was to know microbial contamination in salted fish on Samarinda. The microbiological test was done on 3 samples. The samples was taken from salted fish producer on Samarinda. The microbiological test include investigation total microbe amount with Total Plate Count (TPC) method and microbiological investigation with Most Probable Number (MPN) method and also identification of Coliform and pathogen bacterial such as Escherichia coli and Salmonella thyposa. The result show that from 3 samples of salted fish were contain microbe contamination, but not exceed the limit which fixed by Indonesian National Standart.
\end{abstract}

Keyword : salted fish, Total Plate Count (TPC), Most Probable Number(MPN), coliform and pathogen bacteria, Indonesian National Standa

\begin{abstract}
ABSTRAK
Penyakit melalui makanan marak terjadi belakangan ini, hal ini terjadi karena kontaminasi baik secara biologi ataupun kimia pada makanan. Ikan adalah salah satu jenis makanan yang besar kemungkinannya untuk mengalami kontaminasi secara biologi. Salah satu cara mencegah terjadinya kontaminasi, yaitu dengan pengawetan dengan pembuatan ikan asin. Penelitian ini dilakukan untuk mengetahui cemaran mikroba pada olahan ikan asin air tawar di Samarinda. Pengujian mikrobiologis dilakukan terhadap 3 sampel ikan asin air tawar yang
\end{abstract}


diambil dari produsen ikan asin di Samarinda, meliputi pemeriksaan angka cemaran mikroba dengan metode Angka Lempeng Total (ALT) dan pemeriksaan mikrobiologis dengan Most Probable Number (MPN), serta pemeriksaan bakteri koliform dan bakteri pathogen seperti Escherichia coli dan Salmonella thyposa. Hasil penelitian menunjukkan bahwa dari 3 sampel ikan asin air tawar terdapat cemaran mikroba namun tidak melebihi batas Standar Nasional Indonesia.

Kata kunci: Ikan Asin, Angka Lempeng Total (ALT), Most Probable Number(MPN), bakteri koliform dan pathogen, Standar Nasional Indonesia

\section{PENDAHULUAN}

Makanan yang aman merupakan faktor yang penting untuk meningkatkan derajat kesehatan masyarakat. Menurut Undang-Undang RI No 7 tahun 1996, keamanan pangan didefinisikan sebagai suatu kondisi dan upaya yang diperlukan untuk mencegah pangan dari kemungkinan cemaran biologis, kimia dan benda lain yang dapat mengganggu, merugikan dan membahayakan kesehatan manusia [1].

Penyakit melalui makanan (food borne disease) dapat berasal dari berbagai sumber seperti dari organisme patogen termasuk bakteri, kapang, parasit dan virus atau dari bahan kimia seperti racun alami, logam berat, pestisida, hormon, antibiotik, bahan tambahan berbahaya dan bahan-bahan pertanian lainnya [2].

Salah satu jenis makanan yang besar kemungkinannya untuk mengalami kontaminasi adalah ikan [3]. Ikan merupakan rantai akhir dari kegiatan rantai makanan di perairan dan merupakan salah satu sumber bahan pangan yang dibutuhkan oleh manusia.

Selain itu ikan cepat mengalami proses pembusukan [3]. Hal ini karena ikan mempunyai kadar air yang tinggi dan kandungan nutrient ikan yang cocok untuk pertumbuhan bakteri pembusuk seperti Acromobacter, Pseudomonas, Micrococcus, dan Bacillus [4]. Salah satu cara mencegah terjadinya kontaminasi, yaitu dengan pengawetan dengan pembuatan ikan asin. Di Indonesia, ikan asin masih menempati posisi penting sebagai salah satu bahan pokok kebutuhan hidup rakyat [3].

Berdasarkan uraian diatas, maka dilakukan penelitian "Analisis Cemaran Mikroba Pada Ikan Asin Air Tawar di Samarinda" untuk mengetahui kualitas dari ikan asin air tawar yang diproduksi di 3 produsen ikan asin di Samarinda.

\section{METODE PENELITIAN}

\section{Bahan}

Bahan-bahan yang digunakan dalam penelitian ini antara lain sampel ikan asin air tawar yaitu ikan asin gabus, aquadest, alkohol 70\%, medium Nutrient Agar (MERCK), Medium Lactose Broth (MERCK), medium Eosin Methylen Blue Agar (MERCK). Medium Salmonella Shigella Agar (MERCK), dan indikator methylen blue. 


\section{Peralatan}

Peralatan yang digunakan dalam penelitian ini antara lain Laminar Air Flow incubator, autoklaf, freezer, timbangan analitik, cawan porselin, spatel logam, tabung reaksi, rak tabung, tabung durham, cawan petri, botol pengencer, labu erlenmeyer, hot plate, spoid $1 \mathrm{~mL}$ dan $10 \mathrm{~mL}$, pembakar spiritus, batang pengaduk, serta colony counter.

\section{Prosedur Penelitian}

\section{Pengambilan Sampel}

Sampel yang akan diuji diperoleh dari 3 produsen ikan asin di Samarinda, Kalimantan Timur. Sampel dibawa ke Laboratorium Farmaka Tropis Fakultas Farmasi Universitas Mulawarman Samarinda untuk diteliti dengan cara disimpan di dalam wadah dari plastik yang telah disterilkan sebelumnya dengan desinfektan dan disinar UV selama 30 menit agar terhindar dari kontaminan yang tidak diinginkan.

2. Penentuan cemaran mikroba pada ikan asin air tawar

Penentuan cemaran mikroba pada sampel menggunakan metode angka lempeng total (ALT). Metode ini mengunakan medium umum untuk pertumbuhan bakteri yaitu medium Nutrient Agar (NA). Sampel yang telah dipreparasi ditimbang sebanyak 1 gram dan diencerkan dengan air steril dan dibuat pengenceran bertingkat, yaitu pengenceran $10^{-2}, 10^{-3}$, dan $10^{-4}$. Kemudian sampel yang telah diencerkan tersebut dimasukkan ke dalam cawan petri steril lalu ditambahkan 10 $\mathrm{mL}$ medium NA dan dihomogenkan, kemudian ditunggu hingga memadat untuk kemudian diinkubasi pada suhu $37^{\circ} \mathrm{C}$ selama $1 \times 24$ jam untuk menumbuhkan bakteri. Selanjutnya sampel diambil dan diamati koloni-koloninya yang tumbuh dan dihitung koloni bakteri dengan colony counter lalu dibandingkan dengan standar produk olahan ikan dengan garam menurut SNI untuk melihat cemaran mikroba yang ada pada sampel ikan asin air tawar.

\section{Pengujian Bakteri Koliform}

Pengujian bakteri koliform menggunakan metode Most Probable Number (MPN). Pada metode ini dilakukan 2 uji yaitu uji praduga dan uji konfirmasi. Uji praduga dilakukan dengan menggunakan medium LB (Lactose Broth) dan indikator methylen blue untuk melihat ada atau tidaknya bakteri koliform dalam sampel yang akan diuji. Sampel yang telah dipreparasi ditimbang 1 gram dan dilakukan pengenceran bertingkat dengan air steril, dibuat pengenceran $10^{-2}, 10^{-3}$, dan $10^{-4}$, diambil $1 \mathrm{~mL}$ dari setiap pengenceran dan dimasukkan ke dalam tabung reaksi steril yang telah dimasukkan tabung durham beserta dengan medium Lactose Broth (LB) dan indikator methylen blue. Sampel kemudian diinkubasi selama $1 \times 24$ jam pada suhu $37^{\circ} \mathrm{C}$. Reaksi Positif adanya bakteri koliform pada uji ini adalah dengan adanya gelembung gas dan perubahan medium menjadi kuning atau keruh 
dibandingkan kontrol negatif pada sampel menandakan reaksi positif terdapatnya bakteri koliform dalam sampel.

\section{Uji Konfirmasi dengan medium EMBA dan SSA}

Hasil pada tabung yang positif kemudian dilakukan uji konfirmasi menggunakan medium-medium yang selektif terhadap bakteri coliform. Medium yang digunakan yaitu medium EMBA dan SSA. Tabung pada uji praduga yang menghasilkan hasil positif diambil 1 ose dan digoreskan secara zig-zag pada medium EMBA dan SSA kemudian diinkubasi selama $1 \times 24$ jam pada suhu $37^{\circ} \mathrm{C}$, diamati dan diperhatikan reaksi positif dari masing-masing medium yang berisi bakteri, dimana reaksi positif untuk medium EMBA adalah tumbuhnya koloni bakteri berwarna hijau metalik, dan untuk medium SSA koloni bakteri yang tumbuh berwarna merah muda.

\section{HASIL DAN PEMBAHASAN}

Menurut SNI 01-2721-2009 ikan asin kering adalah suatu produk olahan ikan dengan cara penggaraman dan pengeringan dalam bentuk utuh atau disiangi atau berupa potongan [5]. Menurut Badan Standarisasi Nasional (2009), batas maksimum cemaran mikroba untuk ikan asin adalah untuk nilai ALT $\left(30^{\circ} \mathrm{C}, 24\right.$ jam) adalah $1 \times 10^{5} \mathrm{koloni} / \mathrm{g}$ dan nilai MPN Escerichia coli adalah kurang dari $3 / \mathrm{g}$ dan negatif bakteri Salmonella [6].

Analisis cemaran mikroba dilakukan melalui penetapan angka lempeng total (ALT), penetapan most probable number (MPN) dan uji konfirmasi lanjutan untuk bakteri Escherichia coli dan Salmonella thyposa menggunakan medium selektif Eosin Methylen Blue (EMBA) dan Salmonella-Shigella Agar (SSA).

Metode ALT (Angka Lempeng Total) merupakan metode kuantitatif yang digunakan untuk mengetahui jumlah mikroba pada suatu sampel. Prinsip metode ALT atau hitung cawan ini adalah jika sel mikroba yang berasal dari sampel yang telah diencerkan dengan air steril dan didapatkan pengenceran bertingkat $10^{-2}, 10^{-3}$, $10^{-4}$ yang masih hidup ditumbuhkan pada medium Nutrient Agar (NA), sel mikroba tersebut akan berkembangbiak dan membentuk koloni yang dapat dilihat langsung dengan mata tanpa menggunakan mikroskop [7]. Hasil pengujian ini kemudian dibandingkan dengan batasan maksimum cemaran mikroba dalam pangan dalam Standar Nasional Indonesia (SNI) 7388 [6].

Tabel 1. Data total cemaran mikroba dengan metode angka lempeng total (ALT)

\begin{tabular}{ccccc}
\hline \multirow{2}{*}{ Sampel } & \multicolumn{2}{l}{ Pengenceran (Jumlah Koloni) } & Pelaporan \\
\cline { 2 - 3 } & $10^{-2}$ & $10^{-3}$ & $10^{-4}$ & \\
Koloni/g)
\end{tabular}


Hasil pengujian total cemaran mikroba menggunakan angka lempeng total (ALT) pada 3 sampel ikan asin air tawar yang berasal dari 3 produsen ikan asin di kota Samarinda dapat dilihat pada Tabel 1, diketahui bahwa nilai ALT pada sampel 1 adalah 1,3 $\times 10^{-4} \mathrm{koloni} / \mathrm{g}$, dan nilai ALT untuk sampel 2 dan 3 adalah 1,9 $\times 10^{-4}$ koloni/g. Dapat dilihat nilai angka lempeng total (ALT) dari ketiga sampel yang diuji masih termasuk ke dalam rentang aman yang dipersyaratkan oleh Standar Nasinal Indonesia (SNI) 7388 tentang batasan maksimum cemaran mikroba dalam pangan, untuk dapat dikonsumsi oleh masyarakat yaitu tidak lebih dari 1,0 $\times 10^{5}$ koloni/g [6].

Metode Most Probable Number (MPN) terdiri dari 2 pengujian yaitu uji praduga dan uji konfirmasi. Uji praduga merupakan uji awal menggunakan medium cair yang mengandung lactose dalam tabung reaksi. Tujuan uji praduga adalah untuk mengetahui keberadaan bakteri koliform dalam makanan maupun minuman yang berasal dari sampel yang telah diencerkan dengan air steril dan didapatkan pengenceran bertingkat $10^{-2}, 10^{-3}, 10^{-4}$. Tabung yang menghasilkan hasil positif pada uji praduga dilanjutkan ke uji konfirmasi menggunakan medium EMBA (Eosin Methylen Blue Agar) dan medium SSA (Salmonella Shigella Agar) yang merupakan medium selektif untuk bakteri Escherichia coli dan Salmonella thyposa [7].

Uji praduga, sampel telah diencerkan dengan air steril dan didapatkan pengenceran bertingkat $10^{-2}, 10^{-3}, 10^{-4}$ kemudian ditumbuhkan dengan medium Lactose Broth (LB) dan telah ditambahkan indikator methylene blue. Medium Lactose Broth (LB) digunakan karena bakteri koliform memiliki enzim $\beta$ galaktosidase yang dapat memfermentasi laktosa dengan cara menghidrolisis laktosa menjadi asam dan gas. Laktosa yang terdapat dalam medium Lactose Broth di fermentasi menjadi alkohol dan membentuk asam karboksilat. Asam karboksilat akan membuat medium menjadi suasana asam, dan dengan berubahnya $\mathrm{pH}$ medium, maka akan membuat medium berwarna kuning dan terlihat keruh karena kerja dari indikator methylene blue. Dari proses fermentasi ini juga akan terbentuk gelembung gas tanda terjadinya proses fermentasi. MPN didasarkan atas aktivitas bakteri tersebut dalam melakukan metabolisme yaitu adanya perubahan warna dari medium dan terbentuknya gas dalam tabung durham yang diletakkan dengan cara terbalik [7]. Hasil pada tabung yang positif yaitu medium menjadi keruh dan adanya gelembung gas dibandingkan dengan tabel MPN.

Tabel 2. Data pelaporan keberadaan bakteri koliform dengan metode most probable number (MPN)

\begin{tabular}{rccccc}
\hline \multirow{2}{*}{ Sampel } & \multicolumn{3}{c}{ Pengenceran } & Nilai MPN & Pelaporan \\
\cline { 2 - 5 } & $10^{-2}$ & $10^{-3}$ & $10^{-4}$ & per $100 \mathrm{~mL}$ & per $5 \mathrm{~mL}$ \\
\hline Produsen 1 & +-- & --- & --- & 4 & $0,2 \mathrm{koloni} / \mathrm{g}$ \\
Produsen 2 & -+- & --- & -- & 4 & $0,2 \mathrm{koloni} / \mathrm{g}$ \\
Produsen 3 & --- & --- & -- & $<3$ & $<0,15 \mathrm{koloni} / \mathrm{g}$ \\
\hline
\end{tabular}


Hasil uji praduga metode MPN dapat dilihat pada Tabel 2, sampel 1 dan 2 positif mengandung bakteri koliform dengan adanya tabung yang positif yaitu ditandai dengan medium yang keruh dan terdapat gelembung gas pada tabung durham. Tabung yang positif pada sampel 1 dan 2 adalah tabung seri pengenceran $10^{-2}$, sehingga untuk seri sampel 1 dan 2 adalah 1-0-0 dengan nilai MPN menurut tabel untuk sampel 1 dan 2 yaitu 0,2 koloni/g per $5 \mathrm{~mL}$, sedangkan pada sampel 3 semua seri tabung hanya menunjukkan perubahan medium menjadi keruh namun tidak ada gelembung gas pada tabung durham, sehingga dikategorikan negatif, karena hasil positif adalah jika terjadi perubahan keruh pada medium dan terdapat gelembung gas pada tabung durham, seri untuk tabung sampel 3 adalah $0-0-0$ dengan nilai MPN dari sampel 3 adalah $<0,15 \mathrm{koloni} / \mathrm{g}$ per $5 \mathrm{~mL}$. Artinya dari ketiga sampel yang diuji masih termasuk ke dalam rentang aman yang dipersyaratkan oleh Standar Nasinal Indonesia (SNI) 7388 tentang batasan maksimum nilai APM dalam pangan, untuk dapat dikonsumsi oleh masyarakat yaitu $<3$ koloni/g [6].

Tabung yang menghasilkan uji positif pada uji praduga menggunakan medium Lactose Broth dilanjutkan ke uji konfirmasi menggunakan medium selektif Eosin Methylen Blue Agar (EMBA) dan Salmonella-Shigella Agar (SSA). Uji konfirmasi dilakukan karena pada uji praduga menggunakan medium lactose broth adalah untuk mengetahui keberadaan bakteri koliform yang merupakan campuran bakteri non fekal dan bakteri fekal yang merupakan indikator adanya bakteri patogenik lain. Dilakukan uji konfirmasi untuk menganalisis jenis bakteri pathogen yang ada menggunakan medium selektif Eosin Methylen Blue Agar (EMBA) untuk bakteri Escherichia coli dan Salmonella-Shigella Agar (SSA) untuk bakteri Salmonella.

Uji konfirmasi pertama menggunakan medium Eosin Methylen Blue Agar (EMBA) untuk bakteri Escherichia coli. Medium ini bersifat selektif menumbuhkan Escherichia coli karena medium ini mengandung eosin yang dapat menghambat pertumbuhan bakteri gram positif dan hanya dapat menumbuhkan bakteri gram negatif. Jika di dalam sampel terdapat bakteri Escherichia coli maka akan terjadi proses fermentasi pada medium yang membuat suasana menjadi asam dan dengan terjadinya perubahan $\mathrm{pH}$ pada medium maka dengan adanya indikator Methylen Blue pada medium akan menghasilkan warna koloni yang spesifik untuk bakteri Escherichia coli yaitu koloni yang berwarna hijau metalik [8].

Hasil uji konfirmasi tabung yang positif mengandung koliform pada uji praduga yang diinokulasikan pada medium Eosin Methylen Blue Agar (EMBA) dapat terlihat pada Gambar 1, dari keempat tabung yang positif tidak ada yang membentuk koloni berwarna hijau metalik pada medium Eosin Methylen Blue Agar (EMBA), koloni yang terbentuk berwarna hitam, sehingga sampel dinyatakan negatif mengandung bakteri Escherichia coli.

Uji konfirmasi kedua dilakukan untuk mengetahui keberadaan bakteri Salmonella-Shigella dalam sampel menggunakan medium selektif SalmonellaShigella Agar (SSA). Medium Salmonella-Shigella Agar (SSA) akan memberikan hasil positif berupa zona kuning diantara koloni hitam pada medium jika terdapat bakteri Salmonella-Shigella pada sampel. Pada medium Salmonella-Shigella Agar (SSA) bakteri Salmonella-Shigella dapat melakukan reduksi tiosulfat menjadi 
sulfat sehingga terlihat sebagai koloni hitam, juga terjadi degradasi laktosa menjadi asam yang diindikasikan dengan terbentuknya warna merah [8].

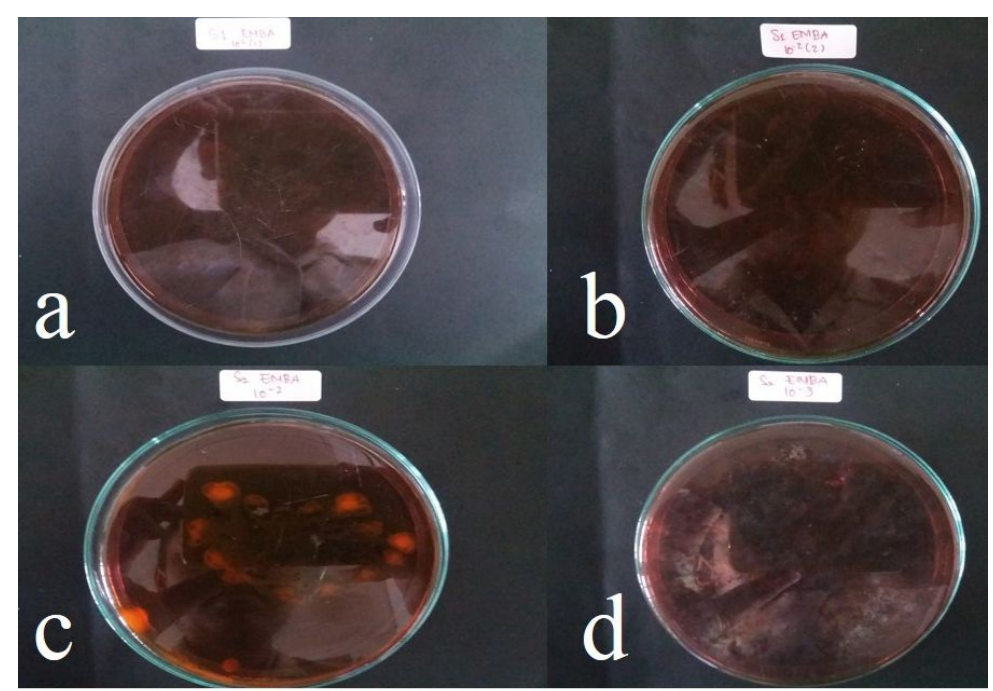

Gambar 1 Hasil identifikasi bakteri Escherichia coli pada (a) sampel 1 pengenceran $10^{-2}(1)$, (b) sampel 1 pengenceran $10^{-2}(2)$, (c) sampel 2 pengenceran $10^{-2}$, dan (d) sampel 2 pengenceran $10^{-3}$. Hasil identifikasi dinyatakan negatif pada medium EMBA karena tidak ada koloni dengan kilap hijau metalik.

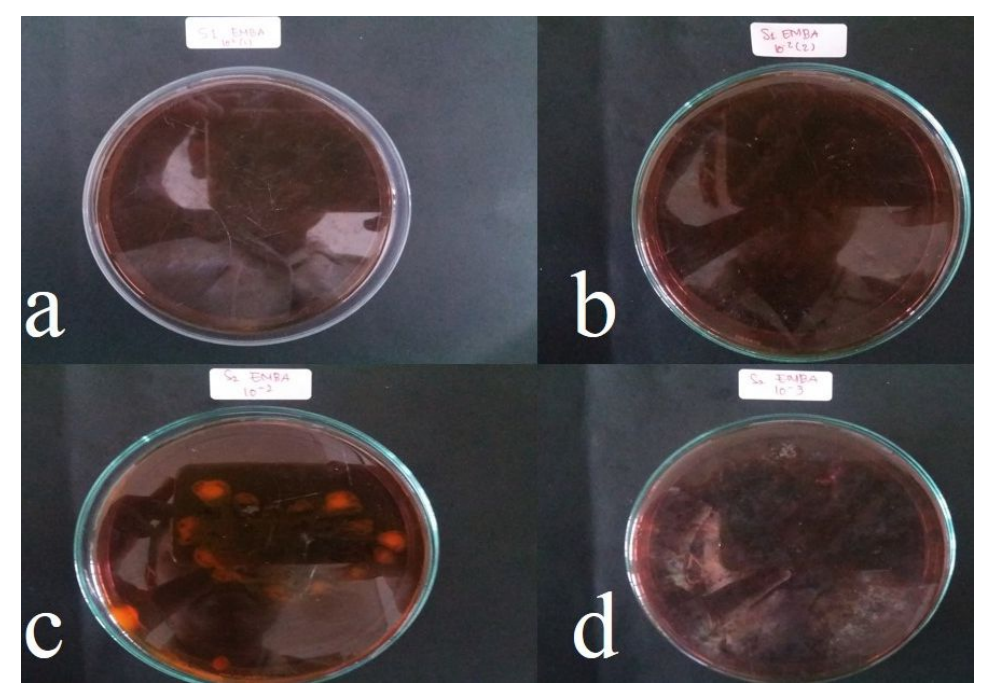

Gambar 2 Hasil identifikasi bakteri Escherichia coli pada (a) sampel 1 pengenceran $10^{-2}(1)$, (b) sampel 1 pengenceran $10^{-2}(2)$, (c) sampel 2 pengenceran $10^{-2}$, dan (d) sampel 2 pengenceran $10^{-3}$. Hasil identifikasi dinyatakan negatif pada medium SSA karena tidak ada koloni yang membentuk koloni dan zona berwarna kuning. 
Uji konfirmasi kedua dilakukan untuk mengetahui keberadaan bakteri Salmonella-Shigella dalam sampel menggunakan medium selektif SalmonellaShigella Agar (SSA). Medium Salmonella-Shigella Agar (SSA) akan memberikan hasil positif berupa zona kuning diantara koloni hitam pada medium jika terdapat bakteri Salmonella-Shigella pada sampel. Pada medium Salmonella-Shigella Agar (SSA) bakteri Salmonella-Shigella dapat melakukan reduksi tiosulfat menjadi sulfat sehingga terlihat sebagai koloni hitam, juga terjadi degradasi laktosa menjadi asam yang diindikasikan dengan terbentuknya warna merah [8].

Hasil uji konfirmasi tabung yang positif mengandung koliform pada uji praduga yang diinokulasikan pada medium Salmonella-Shigella Agar (SSA) dapat terlihat pada Gambar 2, dari keempat tabung yang positif tidak ada yang membentuk zona kuning pada medium Salmonella-Shigella Agar (SSA), sehingga sampel dinyatakan negatif mengandung bakteri Salmonella-Shigella.

Persyaratan batas cemaran bakteri pada olahan ikan menurut Standar Nasional Indonesia (SNI) 7388 tentang batasan maksimum cemaran mikroba dalam pangan mencantumkan bahwa bakteri Salmonella dan Vibrio cholera tidak boleh ada pada produk olahan ikan asin dan untuk Escherichia coli maksimum hanya boleh terdapat $3 \mathrm{MPN} / \mathrm{gram}$. Sehingga dari semua sampel masih memenuhi standar kelayakan untuk isan asin kering menurut SNI 7388 [6].

\section{KESIMPULAN}

Berdasarkan penelitian yang telah dilakukan dapat disimpulkan bahwa semua sampel ikan asin air tawar yang berasal dari 3 produsen ikan asin di Samarinda yang diuji angka cemaran mikrobanya masih termasuk dalam batas yang telah ditetapkan pada Standar Nasional Indonesia (SNI) tahun 2009 tentang batasan maksimum cemaran mikroba pada olahaan ikan dan garam, yaitu tidak lebih dari $1,0 \times 10^{5} \mathrm{koloni} / \mathrm{g}$ untuk nilai ALT dan tidak lebih dari 3 koloni/g untuk nilai MPN. Semua sampel tersebut tidak mengandung bakteri Escherichia coli dan Salmonella thyposa berdasarkan hasil uji konfirmasi menggunakan medium EMBA dan SSA.

\section{DAFTAR PUSTAKA}

[1] Agustina, Titin. 2010. Kontaminasi Logam Berat Pada Makanan dan Dampaknya Pada Kesehatan. TEKNUBUGA, 2(2), 53-65.

[2] Fardiaz, Srikandi. 1992. Polusi Air dan Udara. Yogyakarta: Penerbit Kanisius.

[3] Hastuti, Sri. 2010. Analisis Kualitatif dan Kuantitatif Formaldehid Pada Ikan Asin Di Madura. AGROINTEK, 14(2), 132-137.

[4] Nurwantoro, Siregar A. 1997. Mikrobiologi Pangan Hewani-Nabati. Penerbit Kansius. Yogyakarta.

[5] Badan Standarisasi Nasional. 2009. SNI 2721.1:2009. Ikan Segar-Bagian 2: Persyaratan Bahan Baku. Badan Standardisasi Nasional (BSN). Jakarta. 
[6] Badan Standarisasi Nasional. 2009. Batas Maksimum Cemaran Mikroba dalam Pangan Standar Nasional Indonesia (SNI) 7388: 2009. Badan Standardisasi Nasional (BSN). Jakarta.

[7] Djide, N. dan Sartini. 2008. Analisis Mikrobiologi Farmasi. Laboratorium Mikrobiologi Farmasi Fakultas Farmasi Universitas Hasanuddin. Makassar.

[8] Bambang, G. A., Fatmawali dan Kojong, N. S. 2014. Analisi Cemaran Bakteri Coliform dan Identifikasi Escherichia coli Pada Air Isi Ulang Dari Depot Di Kota Manado. Jurnal Ilmiah Farmasi, 3 (3), 2302-2493. 